\title{
Solid Pseudopapillary Neoplasm of the Pancreas: Analysis of Seven Cases
}

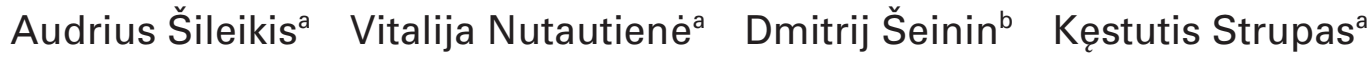 \\ ${ }^{a}$ Center of Abdominal Surgery, Vilnius University, \\ ${ }^{b}$ National Center of Pathology, Vilnius, Lithuania
}

\section{Keywords}

Solid pseudopapillary neoplasm - Pancreas .

Surgical treatment

\section{Summary}

Background: The purpose of this study was to describe as well as compare our surgical treatment experiences of solid pseudopapillary neoplasms (SPN) of the pancreas and to provide a review of the literature. Methods: A retrospective analysis of data from Vilnius University Hospital Santariskiu Klinikos (VUH SK) and of the literature, which was researched using Karger Publishers, Springer Science, BioMed Central, and disserCat databases, was conducted. Results: From 2001 to 2012, seven cases were identified with pathologically confirmed SPN diagnosis. A precise preoperative diagnosis was made by computertomography and magnetic resonance imaging. The median diameter of the tumors was $6.36 \mathrm{~cm}$ (range 1.5-12 cm). Surgical treatment was undertaken for all patients. Results of the immunohistochemical analysis confirmed a nuclear accumulation of $\beta$-catenin. The Ki-67 level was $1-2 \%$ in all of the cases. According to our collected data, all types of histological analysis revealed decent prognostic behavior with low mitotic activity (1-2 mitoses per 50 high power fields). Besides, angioinvasion, perineural invasion, and outside capsule invasion were not detected. Conclusions: There was no correlation between more aggressive types of SPN and tumor size, localization, age, and gender.
Schlüsselwörter

Solider pseudopapillärer Tumor · Pankreas .

Chirurgische Behandlung

\section{Zusammenfassung}

Hintergrund: Ziel dieser Studie war es, unsere chirurgischen Behandlungserfahrungen bei soliden pseudopapillären Neoplasien (SPN) der Bauchspeicheldrüse zu beschreiben und zu vergleichen sowie einen Überblick über die Literatur zu geben. Methoden: Eine retrospektive Analyse anhand der Daten des Vilnius University Hospital Santariskiu Klinikos (VUH SK) und der Literatur anhand der Datenbanken des Karger Verlags, von Springer Science, von BioMed Central und von disserCat wurde durchgeführt. Ergebnisse: Für den Zeitraum von 2001 bis 2012 wurden sieben Fälle mit pathologisch bestätigter Diagnose von SPN identifiziert. Eine genaue präoperative Diagnose wurde mittels Computertomographie und Magnetresonanztomographie vorgenommen. Der mediane Durchmesser der Tumoren betrug 6,36 cm (Bereich 1,5-12 cm). Bei allen Patienten wurde ein chirurgischer Eingriff durchgeführt. Die Ergebnisse der immunhistochemischen Analyse bestätigten eine Kernakkumulation von $\beta$-Catenin. In allen Fällen betrug der Ki-67-Wert 1-2\%. Gemäß unserer gesammelten Daten zeigten alle Varianten der histologischen Analyse ein annehmbares prognostisches Verhalten mit niedriger mitotischer Aktivität (1-2 Mitosen auf 50 Hauptgesichtsfelder). Angioinvasion, perineurale Invasion und Kapselinvasion wurden nicht festgestellt. Schlussfolgerungen: Es bestand kein Zusammenhang zwischen aggressiven Arten von SPN sowie Tumorgröße, Lokalisation, Alter und Geschlecht.

\section{KARGER \\ Fax +497614520714 \\ Information@Karger.com}

www.karger.com (c) 2014 S. Karger GmbH, Freiburg

$1662-6664 / 14 / 0303-0211 \$ 39.50 / 0$

Accessible online at:

www.karger.com/vim 


\section{Introduction}

Solid pseudopapillary neoplasm (SPN) of the pancreas, which was first reported on by Frantz in 1959 [1], is a rare epithelial tumor composed of monomorphous cells forming solid and pseudopapillary structures, frequently with hemorrhagic cystic changes with low malignant potential [2]. Criteria that could distinguish potentially malignant tumors, classified as a solid pseudopapillary carcinoma, include the following: i) perineural invasion, ii) angioinvasion, iii) deep invasion into the surrounding tissues, and iv) distant metastases [3]. SPN represents $1-3 \%$ of all pancreatic tumors and $10-15 \%$ of cystic tumors of the pancreas [4-6]. SPN predominantly affects females during their reproductive phase and exhibits relatively indolent biological behavior with a favorable prognosis $[6,7]$. A metastatic disease is uncommon and only occurs in about $15-20 \%$ of the patients. The overall mortality due to this type of tumor is estimated to be approximately $2 \%$; the recurrence rate after surgery is estimated to encompass $10-15 \%$ of the patients [8]. There are limited reports on this neoplasm as it is rare; according to the literature review by Lin et al. from 2010 [9], 1,014 SPN patients were described. Preoperative diagnosis of SPN provides important management information for clinicians as its indolent clinical behavior compares favorably with other more aggressive pancreatic neoplasms.

\section{Patients and Methods}

A retrospective analysis of medical documentation data of the patients who underwent surgery for SPN between 2001 and 2012 was undertaken at Vilnius University Hospital Santariskiu Klinikos (VUH SK). Other scientific sources, i.e. Karger Publishers, Springer Science, BioMed Central, and disserCat databases, were searched and consulted.

\section{Results}

From 2001 to 2012, SPNs amounted to $0.5 \%$ of all performed pancreatic operations for pancreatic and periampullar tumors at VUH SK. 7 patients with pathologically confirmed SPN diagnosis were identified (table 1). The group of SPN patients included $6(85.7 \%)$ females and $1(14.3 \%)$ male, with an average age of 30.9 years (range $8-60$ years). All patients underwent testing of tumor markers (CA 19-9, CEA), whereas normal levels were detected. Correct SPN diagnosis was made before the surgery in all cases: Diagnoses of 6 patients were revealed by computed tomography (CT) (fig. 1a, b), and the doubtful diagnosis of 1 patient was specified after magnetic resonance imaging (MRI) (fig. 1c). The clinical data of our group revealed that $14.3 \%$ of SPNs were located in the head, $28.6 \%$ in the body, $28.6 \%$ in the body and tail, and $28.6 \%$ in the tail of the pancreas. Median diameter of the tumors was $6.36 \mathrm{~cm}$ (range 1.5-12 cm). 5 patients with a tumor diameter $>6 \mathrm{~cm}$ were identified. Pancreas resection and extirpation were performed for 5 and for 2 patients, respectively. A more aggressive surgery type with selective lymphadenectomy was applied to 4 patients. Lymph node enlargements were confirmed to be benign. Distal metastases were not detected. Results of immunohistochemical analysis revealed a nuclear accumulation of $\beta$-catenin. The Ki-67 level was $1-2 \%$ in all of the cases. There was no correlation between more aggressive types of SPN and a larger tumor size. According to clinical data of the patients, all types of pathohistochemical analyses revealed a decent prognostic behavior with low mitotic rate. A yearly follow-up was performed for the years 1-11. No recurrence of the disease was identified.

\section{Discussion}

SPNs are characterized by mutations in exon 3 of CTNNB1 [10] that predispose cells to the dysregulation and redistribution of $\beta$-catenin, which is an integral component of the E-cadherin complexes at the intercellular adherence junctions [11]. The protein also plays a key role in the Wnt signaling pathway as a transcriptional activator in conjunction with T-cell factor/ lymphoid enhancer factor, with the transcription factors inducing the target gene expression that is required for cell proliferation and differentiation [12]. Mutations in the $\beta$-catenin gene which impaired adhesion may be one of the factors accounting for the pseudopapillary appearance [10]. Wnt/ $\beta$-catenin, hedgehog, and androgen receptor signaling pathway activation as well as genes involved in epithelial mesenchymal transition are closely associated with lesser epithelial cell differentiation than other common pancreatic tumors, therefore suggesting that it might be a hormone-dependent tumor [13].

SPN arises from primitive pancreatic cells (e.g. acinar cells, ductal epithelial cells, or endocrine cells) or from cell lines of the female genital bud [8].

In general, SPN occurs predominantly in young women $(86.5 \%)$ and is rare in men $(13.5 \%)$. Men are on average 5 years older, have a twice as high incidence of metastases (women: $4.3 \%$; men: $10.2 \%$ ) and invasive malignancy (women: $12.4 \%$; men: $24.4 \%$ ), and show a threefold higher death rate (women: 3.6\%; men: 11.4\%) [9]. Approximately $20-25 \%$ of the cases are determined in pediatric patients. SPNs usually form large masses, with a mean diameter of $6 \mathrm{~cm}$ and range of $0.5-34.5 \mathrm{~cm}$ [7], and are mostly distributed in the pancreatic head $(39.8 \%)$, tail $(24.1 \%)$, and body and tail (19.5\%) [14]. The clinical presentation of SPN is non-specific. Most of the patients present with non-specific symptoms including abdominal discomfort, mild abdominal pain, or palpable abdominal mass. Due to its slow growth, SPN often remains asymptomatic until the tumor enlarges considerably; accordingly, the majority of SPNs is detected incidentally during diagnostic imaging for unrelated diseases [15].

Concerning diagnostics, routine laboratory parameters and tumor markers are of no help. CT/MRI scans typically show a 
Table 1. Pathologically confirmed SPN patient data of VUH SK

\begin{tabular}{|c|c|c|c|c|c|c|c|}
\hline Parameters & $\mathrm{P} 1$ & $\mathrm{P} 2$ & P3 & $\mathrm{P} 4$ & P5 & P6 & $\mathrm{P7}$ \\
\hline Age, years & 17 & 8 & 37 & 28 & 25 & 60 & 41 \\
\hline Gender & female & male & female & female & female & female & female \\
\hline $\begin{array}{l}\text { Localization of } \\
\text { pancreatic tumor }\end{array}$ & head & body & body and tail & body and tail & body & tail & tail \\
\hline $\begin{array}{l}\text { Tumor size, } \mathrm{cm} \\
\text { Tumor tissue } \\
\text { characteristics }\end{array}$ & $\begin{array}{l}8 \times 8 \times 7 \\
\text { solid cystic }\end{array}$ & $\begin{array}{l}2 \times 2 \times 2 \\
\text { solid }\end{array}$ & $\begin{array}{l}6 \times 5 \times 4 \\
\text { solid }\end{array}$ & $\begin{array}{l}6 \times 4.5 \times 2.7 \\
\text { solid }\end{array}$ & $\begin{array}{l}1.5 \times 1.5 \times 1.5 \\
\text { solid }\end{array}$ & $\begin{array}{l}12 \times 12 \times 12 \\
\text { cystic }\end{array}$ & $\begin{array}{l}8 \times 9 \times 8 \\
\text { cystic }\end{array}$ \\
\hline Surgery type & extirpation & $\begin{array}{l}\text { segmental } \\
\text { resection }\end{array}$ & extirpation & $\begin{array}{l}\text { left } \\
\text { hemipancreatectomy }\end{array}$ & $\begin{array}{l}\text { segmental } \\
\text { resection }\end{array}$ & $\begin{array}{l}\text { distal } \\
\text { resection }\end{array}$ & $\begin{array}{l}\text { distal } \\
\text { resection }\end{array}$ \\
\hline Lymph nodes & 6 & 1 & - & 12 & 1 & 5 & 3 \\
\hline Mitotic activity index & 1 per $50 \mathrm{HPF}$ & 2 per $50 \mathrm{HPF}$ & 1 per $50 \mathrm{HPF}$ & 1 per $50 \mathrm{HPF}$ & 2 per $50 \mathrm{HPF}$ & 1 per $50 \mathrm{HPF}$ & 2 per $50 \mathrm{HPF}$ \\
\hline $\mathrm{Ki}-67$ & $1-2 \%$ & $2 \%$ & $1 \%$ & $1 \%$ & $1 \%$ & $1 \%$ & $1 \%$ \\
\hline
\end{tabular}

$\mathrm{HPF}=$ High power fields.

Fig. 1. a CT scan reveals encapsulated, round, non-homogenic mass of pancreatic head. b CT scan reveals SPN with peripheral calcifications of the capsule. c MRT imaging in $\mathrm{T} 2$ sequence reveals round, well-defined peripheral capsule of SPN in the body of the pancreas.
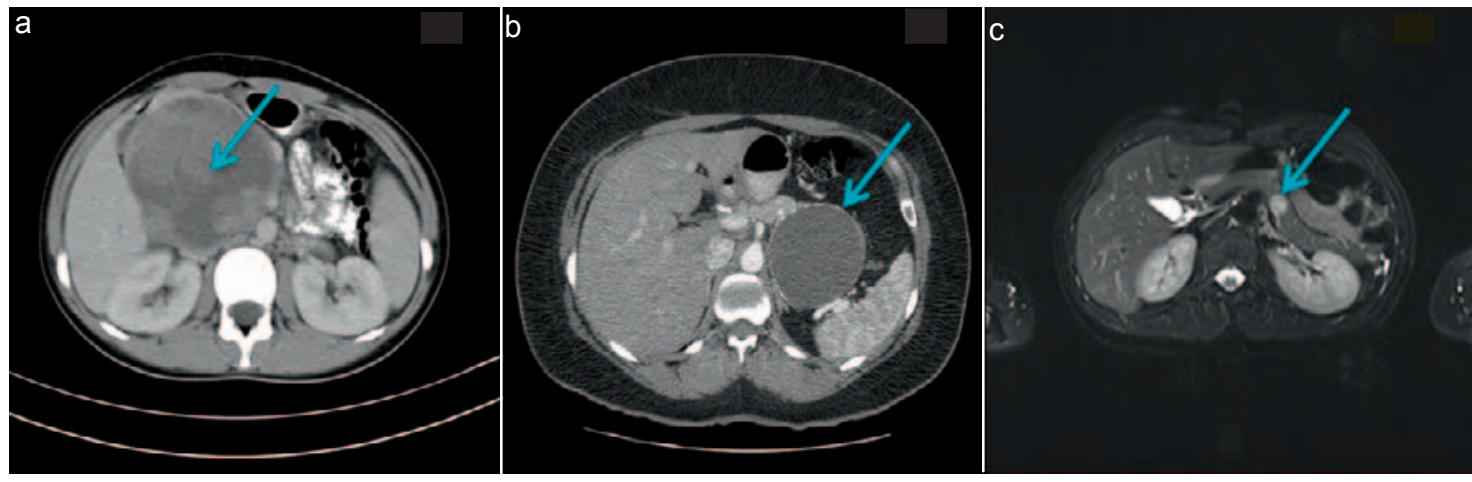

large, well-circumscribed (97\%), heterogeneous mass with varying solid and cystic components, generally demarcated by enhancing capsule (77\%). These tumors tend to be predominantly round or oval $(66 \%)$, demonstrate well-defined, often contained, either peripheral or central calcifications (47\%), and overwhelmingly show no evidence of biliary dilatation, pancreatic ductal dilatation, or pancreatic parenchymal atrophy. Despite the large size of these tumors, vascular encasement or occlusion is quite rare $(13 \%)$, although the large size of the masses sometimes leads to considerable displacement of the adjacent vasculature. MRI is superior to CT in distinguishing certain tissue characteristics, such as hemorrhage, cystic degeneration, or the presence of a capsule, and may enable correct diagnosis [16]. CT scans might help to diagnose SPNs accurately in $80 \%$ of the cases [17]. In 2012, Yin et al. [18] described some characteristic features based on CT and/ or MRI which can differentiate between benign and malignant SPNs. Focal discontinuity of the capsule, large tumor size $(>6.0 \mathrm{~cm})$, and pancreatic tail location may suggest malignancy of SPN. In contrast, tumors with amorphous or scattered calcifications and all near-solid tumors may be indicative of benignancy.

An accurate preoperative diagnosis would be helpful in surgical planning. In uncertain cases, the diagnosis can be con- firmed by endoscopic ultrasound scan with fine-needle aspiration (FNA) biopsy or percutaneous core needle biopsy with ultrasound or CT guidance.

The classic morphologic findings on FNA include branching papillary-like fronds composed of central fibrovascular cores with attached small uniform tumor cells. The neoplastic cells also present as small aggregates, rosettes, and numerous single cells, which may be plasmacytoid. The cytoplasm is pale, ill-defined, and variable in amount. Occasionally cytoplasmic vacuoles might be found. The nuclei are round to oval with fine, evenly dispersed chromatin and nuclear grooves. Positive immunocytochemistry for $\beta$-catenin (nuclear staining), CD10, vimentin, CD56, and $\alpha 1$-antitrypsin led to the correct diagnosis of SPN.

Clear-cut criteria of malignancy have not been established. Features that may indicate an aggressive clinical behavior are venous invasion, diffuse infiltrative growth pattern, extensive tumor necrosis, significant nuclear atypia, high mitotic count, nuclear pleomorphism, DNA aneuploidy, double loss of $\mathrm{X}$ chromosomes, trisomy of chromosome 3, and unbalanced translocation between chromosomes 13 and 17 [20, 21].

Unlike most other pancreatic tumors, malignant behavior of SPN is observed in about $10-15 \%$ of the cases. Metastases 
were described in regional lymph nodes, liver, and peritoneum/omentum [7]. Given their low malignant potential and the excellent overall prognosis, surgical resection has been the standard of care in the management of SPN. SPN can be treated by complete tumor resection with limited resection or a minimally invasive approach, when applicable. The combination of surgical resection and chemotherapy by paclitaxel may therefore prolong survival, even in malignant cases [22]. Tumor enucleation and incomplete excision should be avoided due to the risk of a higher recurrence rate [23]. Despite this fact, there was no recurrence determined for the patients treated with extirpation at VUH SK. Extensive lymphatic dissection or resection of adjacent structures is not suggested since lymph node metastases are found in $<2 \%$ [24, 25]. In our cases, all histologically examined lymph nodes were negative for metastatic disease. Tumor size should not be regarded as a predictor of unresectability because lesions as large as $30 \mathrm{~cm}$ may be resected without problems [26]. Unlike other pancreatic tumors, the stage of the disease does not play any role in the treatment of SPN [24]. If veins are infiltrated, vascular en bloc resection and reconstruction with vein grafts has been proposed, and the results were encouraging [24]. Neoadjuvant chemotherapy or radiotherapy is not indicated for treatment $[27,28]$. The overall 5-year survival rate approaches $97 \%$ in patients undergoing surgical resection [24, 29].

\section{Conclusion}

SPN is a rare pancreatic neoplasm of unclear histogenesis that typically affects young females without significant symptoms. Appearance on imaging is fairly characteristic and may suggest diagnosis. In uncertain cases, preoperative diagnosis should be accomplished by FNA biopsy in order to avoid not indicated preoperative chemotherapy or radiotherapy. Complete surgical resection of the tumor is the only effective treatment option.

\section{Disclosure Statement}

The authors did not provide a conflict of interest statement.

\section{References}

${ }_{1}$ Frantz VK: Tumors of the pancreas; in Armed Forces Institute of Pathology: Atlas of Tumor Pathology. Washington DC, Armed Forces Institute of Pathology, 1959, pp 32-33.

2 Kloppel G, Solcia E, Longnecker DS, Capella C, Sobin LH: Histological typing of tumors of the exocrine pancreas; in World Health Organization: International Histological Classification of Tumors, ed 2. New York, Springer, 1996, pp 15-21.

3 Kloppel G, Luttges J, Klimstra DS: Solid-pseudopapillary neoplasm; in Hamilton SR, Aaltonene LA (eds): World Health Organization Classification of Tumors: Pathology and Genetics of Tumors of the Digestive System. Lyon, IARC, 2000, pp 246-248.

4 Allen P, D'Angelica M, Gonen M, Jaques DP, Coit DG, Jarnagin WR, DeMatteo R, Fong Y, Blumgart LH, Brennan MF: A selective approach to the resection of cystic lesions of the pancreas: results from 539 consecutive patients. Ann Surg 2006;244:572-582.

$\checkmark 5$ Adams AL, Siegal GP, Jhala NC: Solid pseudopapillary tumor of the pancreas. A review of salient clinical and pathologic features. Adv Anat Patho 2008;15:572-582.

6 Lam KY, Lo CY, Asanuma K, Fan ST: Pancreatic solid-cystic-papillary tumor: clinicopathologic features in eight patients from Hong Kong and review of the literature. World J Surg 1999;23:1045-1050.

7 Papavramidis T, Papavramidis S: Solid pseudopapillary tumors of the pancreas: review of 718 patients reported in English literature. J Am Coll Surg 2005;200:965-972.

8 Geers C, Moulin P, Gigot JF, Weynand B, Deprez P, Rahier J, Sempoux C: Solid and pseudopapillary tumor of the pancreas - review and new insights into pathogenesis. Am J Surg Pathol 2006;30:1243-1249.

$\checkmark 9$ Lin MY, Stabile BE: Solid pseudopapillary neoplasm of the pancreas: a rare and atypically aggressive disease among male patients. Am Surg 2010; 76:1075-1078.
10 Tanaka Y, Kato K, Notohara K, Hojo H, Ijiri R, Miyake T, Nagahara N, Sasaki F, Kitagawa N, Nakatani Y, Kobayashi Y: Frequent beta-catenin mutation and cytoplasmic/nuclear accumulation in pancreatic solid-pseudopapillary neoplasm. Cancer Res 2001;61:8401-8404.

11 Baum B, Georgiou M: Dynamics of adherens junctions in epithelial establishment, maintenance, and remodeling. J Cell Biol 2011;192:907-917.

12 Clevers H: Wnt/beta-catenin signaling in development and disease. Cell 2006;127:469-480.

13 Park M, Kim M, Hwang D, Park M, Kim WK, Kim SK, Shin J, Park ES, Kang CM, Paik YK, Kim H: Characterization of gene expression and activated signaling pathways in solid-pseudopapillary neoplasm of pancreas. Mod Pathol Online 2013;10:154-161.

14 Yu PF, Hu ZH, Wang XB, Guo JM, Cheng XD, Zhang YL, Xu Q: Solid pseudopapillary tumor of the pancreas: a review of 553 cases in Chinese literature. World J Gastroenterol 2010;16:1209-1214.

15 Reddy S, Cameron JL, Scudiere J, Hruban RH, Fishman EK, Ahuja N, Pawlik TM, Edil BH, Schulick RD, Wolfgang CL: Surgical management of solid-pseudopapillary neoplasms of the pancreas (Franz or Hamoudi tumors): a large single-institutional series. J Am Coll Surg 2009;208:950-959.

16 Raman SP, Kawamoto S, Law JK, Blackford A, Lennon AM, Wolfgang CL, Hruban RH, Cameron JL, Fishman EK: Institutional experience with solid pseudopapillary neoplasms: focus on computed tomography, magnetic resonance imaging, conventional ultrasound, endoscopic ultrasound, and predictors of aggressive histology. J Comput Assist Tomogr 2013;37:824-833.

17 Machado MC, Machado MA, Bacchella T, Jukemura J, Almeida JL, Cunha JE: Solid pseudopapillary neoplasm of the pancreas: distinct patterns of onset, diagnosis, and prognosis for male versus female patients. Surgery 2008;143:29-34.
18 Yin Q, Wang M, Wang C, Wu Z, Yuan F, Chen K, Tang Y, Zhao X, Miao F: Differentiation between benign and malignant solid pseudopapillary tumor of the pancreas by MDCT. Eur J Radiol 2012;81: 3010-3018.

19 Zhao P, Debrito P, Ozdemirli M, Sidawy MK: Solid-pseudopapillary neoplasm of the pancreas: awareness of unusual clinical presentations and morphology of the clear cell variant can prevent diagnostic errors. Diagn Cytopathol 2013;41:889-895.

20 Pettinato G, Manivel JC, Ravetto C, Terracciano LM, Gould EW, di Tuoro A, Jaszcz W, AlboresSaavedra J: Papillary cystic tumor of the pancreas. A clinicopathologic study of 20 cases with cytologic, immunohistochemical, ultrastructural and flow cytometric observations and a review of the literature. Am J Clin Pathol 1992;98:478-488.

21 Serra S, Chetty R: Revision 2: an immunohistochemical approach and evaluation of solid pseudopapillary tumour of the pancreas. J Clin Pathol 2008;61:1153-1159.

22 Morikawa T, Onogawa T, Maeda S, Takadate T, Shirasaki K, Yoshida H, Ishida K, Motoi F, Naitoh T, Rikiyama T, Katayose Y, Egawa S, Unno M: Solid pseudopapillary neoplasms of the pancreas: an 18-year experience at a single Japanese Institution. Surg Today 2013;43:26-32.

23 Vassos N, Agaimy A, Klein P, Hohenberger W, Croner RS: Solid-pseudopapillary neoplasm (SPN) of the pancreas: case series and literature review on an enigmatic entity. Int J Clin Exp Pathol 2013;6: 1051-1059.

24 Martin RC, Klimstra DS, Brennan MF, Conlon KC: Solid-pseudopapillary tumor of pancreas: a surgical enigma? Ann Surg Oncol 2002;9:35-40.

25 Yoon DY, Hines OJ, Bilchik AJ, Lewin K, Cortina G, Reber HA: Solid and papillary epithelial neoplasms of the pancreas: aggressive resection for cure. Am Surg 2001;67:1195-1199. 
26 Vollmer CM, Dixon W, Grant DR: Management of a solid pseudopapillary tumor of the pancreas with liver metastases. HPB (Oxford) 2003;5:264-267.

-27 Das G, Bhuyan C, Das BK, Sharma JD, Saikia BJ, Purkystha J: Spleen-preserving distal pancreatectomy following neoadjuvant chemotherapy for papillary solid and cystic neoplasm of pancreas. Ind J Gastroenterology 2004;23:188-189.
28 Matsunou H, Konishi F: Papillary-cystic neoplasm of the pancreas: a clinicopathologic study concerning the tumor aging and malignancy of nine cases. Cancer 1990;65:283-291.
29 Tang LH, Aydin H, Brennan MF, Klinstra DS: Clinically aggressive solid pseudopapillary tumor of pancreas: a report of cases with components of undifferentiated carcinoma and a comparative clinicopathologic analysis of 34 conventional cases. Am J Surg Pathol 2005;29:512-519. 